\title{
Histomorphometrical analysis on the effects of two therapeutic ultrasound intensities on fracture healing in aged rats
}

\author{
Estudo histomorfométrico comparativo dos efeitos \\ de duas intensidades de ultrassom terapêuticos na \\ consolidação de fratura da tíbia em ratos idosos
}

\author{
Jeronimo Rafael Skau ${ }^{[a]}$, Bruno Rodrigues ${ }^{[b]}$, Felipe Oliveira Rosa ${ }^{[c]}$, Rubens Correa Araujo ${ }^{[\mathrm{d}]}$, \\ Renata Gabriel Fontinele ${ }^{[\mathrm{e}]}$, Romeu Rodrigues de Souza ${ }^{[\mathrm{f}]}$
}

[a] MSc, Universidade São Judas Tadeu, Departamento de Fisioterapia, São Paulo, SP - Brazil, e-mail: jrskau@gmail.com

[b] PhD, Universidade São Judas Tadeu, Departamento de Fisioterapia, São Paulo, SP - Brazil, e-mail: prof.brodrigues@usjt.br

[c] MSc, Universidade de São Paulo, Departamento de Anatomia, São Paulo, SP - Brazil, e-mail: feliperzoliv@aol.com

[d] PhD, Universidade de Taubaté, Departamento de Fisioterapia, Taubaté, SP - Brazil, e-mail: prof.raraujo@usjt.br

[e] PhD, Universidade de São Paulo, Departamento de Anatomia, São Paulo, SP - Brazil, e-mail: renata.fontenele@globo.com

[f] PhD, Universidade São Judas Tadeu, Universidade de São Paulo, Departamento de Anatomia, São Paulo, SP - Brazil, e-mail: souzarrd@uol.com.br

\begin{abstract}
Introduction: Experimental studies conducted in young animals show that therapeutic ultrasound (TUS) has been successfully used to shorten the healing time of bone fractures. However, they were not found in the literature, studies comparing the effect of different intensities of UST in aged animals. Objective: To test the efficacy of intensity $1.0 \mathrm{~W} / \mathrm{cm}^{2}$ and of $0.5 \mathrm{~W} / \mathrm{cm}^{2}$ in the consolidation of experimental fracture of the tibia from aged Wistar rats. Materials and methods: Three groups of 15 month old rats were submitted to a midshaft osteotomy of the tibia and then, the hind member was immobilized with a metal splint and plaster of Paris, wrapping the knee and ankle joint. One group (L), received ultrasound at $0.5 \mathrm{~W} / \mathrm{cm}^{2}$; the other group (I), were exposed to ultrasound at $1.0 \mathrm{~W} / \mathrm{cm}^{2}$. One control group (C), did not receive the ultrasound. Fifteen animals (five from each group) were euthanatized at the end of the first week and fifteen (five from each group) at the end of the third week. The progress of the fracture healing was performed for each group by morphometric analysis of histological sections of the fracture region. Results and conclusion:
\end{abstract}


The results showed that fractures treated with ultrasound at $1.0 \mathrm{~W} / \mathrm{cm}^{2}$ healed significantly faster than did the fractures treated with ultrasound at $0.5 \mathrm{~W} / \mathrm{cm}^{2}$ and the control.

Keywords: Ultrasound. Wound healing. Bone fracture. Aging.

\section{Resumo}

Introdução: Trabalhos experimentais realizados em animais jovens mostram que o ultrassom terapêutico (UST) tem sido utilizado com sucesso para abreviar o tempo de consolidação de fraturas ósseas. Entretanto, não foram encontrados na literatura, trabalhos comparando o efeito de diferentes intensidades de UST em animais idosos. Objetivo: Comparar a eficácia de duas intensidades de UST, de 0,5 W/ $\mathrm{cm}^{2}$ e de $1,0 \mathrm{~W} / \mathrm{cm}^{2} \mathrm{na}$ consolidação de fratura experimental da tíbia de ratos Wistar idosos. Materiais e métodos: Três grupos de ratos com 15 meses de idade foram submetidos a osteotomia da diáfise da tíbia e a seguir o membro inferior foi imobilizado com uma barra de metal, tornando imóveis as articulações do joelho e do tornozelo. Um grupo de animais (L) recebeu UST a 0,5 W/cm ; o outro grupo (I) foi submetido ao UST de 1,0 W/cm ${ }^{2}$. Um grupo controle (C) não recebeu aplicação de UST. Quinze animais (cinco por grupo) foram sacrificados após uma semana e outros quinze animais (cinco por grupo) após três semanas de imobilização. O progresso de consolidação da fratura foi obtido para cada grupo através de avaliação morfométrica de cortes histológicos da região da fratura. Resultados e conclusão: Os resultados obtidos mostram que, em ratos idosos, as fraturas tratadas com UST de $1,0 \mathrm{~W} / \mathrm{cm}^{2}$ consolidaram mais rapidamente que as tratadas com o UST de $0,5 \mathrm{~W} / \mathrm{cm}^{2}$ e as do grupo $C$.

Palavras-chave: Ultrasom. Cicatrização. Fratura óssea. Envelhecimento.

\section{Introduction}

One of the most common kinds of fractures, both in the young and elderly is that of the middle third of the tibia (1). In the repair process of such kind of fracture (stable bone fracture), after the removal of the blood clot by cells of the connective tissue, there is an initial proliferation of osteogenic cells (2), that is followed by the appearance of minuscule bone and cartilaginous strands and fibrous tissue in the area. As a result, immature bone tissue is formed, and then the lamellated bone tissue appear constituting the bone callus (3). This entire process generally takes between 10 and 13 weeks in humans and 3 weeks in young rats (4).

Several works have been carried out searching for methods to abbreviate the time for fracture consolidation $(4,5)$. Methods that have been used to accelerate bone healing include electrical stimulation, therapeutic ultrasound (TUS) and precocious mobilization, among others. Low-intensity pulsed ultrasound has been shown to accelerate fracture healing in both animal models and clinical trials $(2$, $6,7,8,9,10,11)$. The effectiveness of this resource has been studied using different degrees of intensity. The values that showed positive results are that of low intensity: $0.5 \mathrm{~W} / \mathrm{cm}^{2}$ and $0.3 \mathrm{~W} / \mathrm{cm}^{2}(7,12)$. The use of high intensities such as those of $1.5 \mathrm{~W} / \mathrm{cm}^{2}$ proved to be detrimental to the bone tissue. However, investigations showing the effects of values between 0.2 and $1.5 \mathrm{~W} / \mathrm{cm}^{2}$ are scarce and have been carried out in young animals $(12,13)$. In this study, the time for fracture consolidation of the middle third of the tibia using two different intensities $\left(0.5 \mathrm{~W} / \mathrm{cm}^{2}\right.$ and $1.0 \mathrm{~W} / \mathrm{cm}^{2}$ ) of pulsating ultrasound were compared by histomorphometric method in aged rats.

\section{Materials and methods}

\section{Surgical proceeding}

In this work, 30 fifteen-mo-old Wistar male rats were used. All the animals were submitted to peridural anesthetics (Xylocayne 2\% and Epinefrine, 1:4000) (Ariston LAB, São Paulo, Brazil). After preparation of the right hindlimb, flexion position was given. $A$ two $\mathrm{cm}$ linear incision was made on the medial aspect of the limb and the tibia was exposed. The tibia was transversally and incompletely divided in its middle third, using an appropriate saw. Then, the skin was sutured and 
the hind limb was immobilized by a metal splint and plaster of Paris, wrapping the knee and ankle joints. Animals were divided into three groups with 10 rats each: Control group (C); Low intensity TUS group (L) and Intermediary intensity TUS group (I). C Group was submitted only to the immobilization. L Group received 1.0 MHz TUS (Sonopulse III Ibramed, Amparo, São Paulo, Brazil) in pulsed mode at $0.5 \mathrm{~W} / \mathrm{cm}^{2}$ for $5 \mathrm{~min}$ utes daily, 5 times a week; 5 animals received TUS for 1 week and 5 for 3 weeks. I Group received $1.0 \mathrm{MHz}$ TUS in pulsed mode at $1.0 \mathrm{~W} / \mathrm{cm}^{2}$, for 5 minutes daily, 5 times a week; 5 animals received TUS for 1 week and 5 for 3 weeks. The application of the TUS was performed through a water balloon. A thin layer of gel was placed on the area of the lesion and on top of the balloon. Then, the balloon was placed over the wound surface area, and the TUS probe was placed over it. The rats were allowed to move freely in their cages. At the end of the first week 15 rats, being 5 from each group were killed and at the end of the $3^{\text {rd }}$ week the last 15 rats, being 5 from each group were also killed. The segment of the tibia with the fracture trace was collected and processed for examination. All procedures to which the animals were submitted received the approval of the Commission of Ethics in the Use of Animals of the Faculdade de Medicina Veterinária of Universidade de São Paulo, which follows the International Guiding Principles for Biomedical Research Involving Animals, under protocol no 734/2005.

\section{Histomorphometry}

From each animal, the segment of the tibia containing the fracture trace was removed, fixed in formaldehyde in $0.07 \mathrm{M}$ phosphate buffer (pH 7.0) and decalcified with 10\% EDTA (Sigma-Aldrich, St. Louis, MO, USA) and $4 \%$ formaldehyde in $0.01 \mathrm{M}$ phosphate buffer ( $\mathrm{pH}$ 7.4) at $4{ }^{\circ} \mathrm{C}$. The blocks were washed in the phosphate buffer and dehydrated, cleared and embedded in Paraplast. Sections 7 micrometers $(\mu \mathrm{m})$ thick were performed parallel to the long axis of the tibia. Every third section of a total of 10 sections was then stained with hematoxylin and eosin (HE) and analysed in a digital image analysis system (KS-400, Carl Zeiss, São Paulo, Brazil).

To estimate the volume density (\%) of neoformed bone ( $V_{\mathrm{v}}$ bone), a test-system with 132 points was superimposed to each image over the monitor screen in the video-microscopic system. The points hitting bone tissue were counted and then the $V_{\mathrm{v}}$ bone was calculated by the formula:

$$
\mathrm{V}_{\mathrm{v}} \text { bone }=\frac{\mathrm{P}_{\mathrm{p}} \text { (bone) }}{\mathrm{P}_{\mathrm{T}}}
$$

Where: PP(bone) are the number of points hitting the bone, and PT are the total number of points (54) of the test-system (14) (Figure 1). The results are expressed as means \pm SEM.

\section{Statistical analysis}

Data were compared by analysis of variance (ANOVA), and Tukey's test for multiple comparisons, as appropriate. The significance level was set at $P<0.05$.

\section{Results}

\section{Histomorphometric analysis}

Qualitatively, at the first week, the C group has an empty space, corresponding to the area of the lesion, showing that the consolidation process has not yet begun (Figure 2A). At third week, proliferation of osteogenic cells can be observed in the lesion area. In the deep part of the lesion, there are recently formed bony trabeculae. Much more osseous tissue was observed in the callus (Figure 2D). In L Group (Figure 2B), at the first week, osteogenic cells fill in the lesion space, indicating that the formation of bone tissue will be initiated. In the third week, newly formed bone fill almost entirely the space of the lesion (Figure 2E). At the first week of the I Group (Figure 2C), newly formed immature bony trabeculae fill the region of the fracture and osteogenic cells can be observed in the lesion space indicating that beginning of primary ossification takes place in the space of lesion. At the third week, bone trabeculae (arrows) can be seen filling almost all space of the fracture (Figure 2F). In conclusion, on day $21^{\text {st }}$ (Figures 2D, 2E, $2 \mathrm{~F}$ ), fractures treated with US at $1.0 \mathrm{~W} / \mathrm{cm}^{2}$ (Figure 2F) healed more rapidly than did that treated with $0.5 \mathrm{~W} / \mathrm{cm}^{2}$ (Figure 2E) or the controls (Figure 2D).

Quantitatively, significant differences on the volume density (\%) of newly formed bone tissue were observed among the groups at the $1^{\text {st }}$ and $3^{\text {rd }}$ week 
$(\mathrm{p}<0.05)$. The percent of the new bone tissue was higher in I (7\%) than in the C (0\%) and L (3\%) group at the first week $(\mathrm{P}<0.05)$. At the third week, the percent of the newly formed bone tissue was higher in L (25\%) than in the C (9\%) group and in I (60\%) than in $\mathrm{L}$ and $\mathrm{C}$ group $(\mathrm{P}<0.05)$ (Figure 3$).$

\section{Discussion}

The consolidation time for the bone fractures that frequently occur both in sports and in aged sedentary people obliges the individuals to remain distant from their normal activities $(2,15,16)$. Application of TUS is among the resources suggested with the objective of recovering the individuals in the shortest possible time. This resource have been used by several authors obtaining positive effects $(2,6,7,8,10,17)$, although some have not obtained favorable results in humans with its application (16).
There is disagreement among authors, related to the best intensity of TUS to be applied in the case of fractures (18). Several authors $(5,12)$ obtained favorable results in fractures of rats treated with $0.1 \mathrm{~W} / \mathrm{cm}^{2}$ for two minutes every 2 days or with 0.2 $\mathrm{W} / \mathrm{cm}^{2}$ for ten minutes over five consecutive days (13). According to others, intensities from $0.3 \mathrm{~W} /$ $\mathrm{cm}^{2}$ to $0.5 \mathrm{~W} / \mathrm{cm}^{2}$ are the most efficient (19). The present study showed that fractures treated with ultrasound at $1.0 \mathrm{~W} / \mathrm{cm}^{2}$ healed significantly faster than that treated with ultrasound at $0.5 \mathrm{~W} / \mathrm{cm}^{2}$ and the control. The fracture healing has been accelerated in TUS $1.0 \mathrm{~W} / \mathrm{cm}^{2}$ group than in the $0.5 \mathrm{~W} / \mathrm{cm}^{2}$ group, both at the first week but mainly at the $3^{\text {rd }}$ week $(\mathrm{p}<0.05)$.

In the present study, tibia was choose due the easy surgical access to this bone, because of its superficial location and because the fracture in the middle third of the tibia is one of the most frequent $(1,20)$.

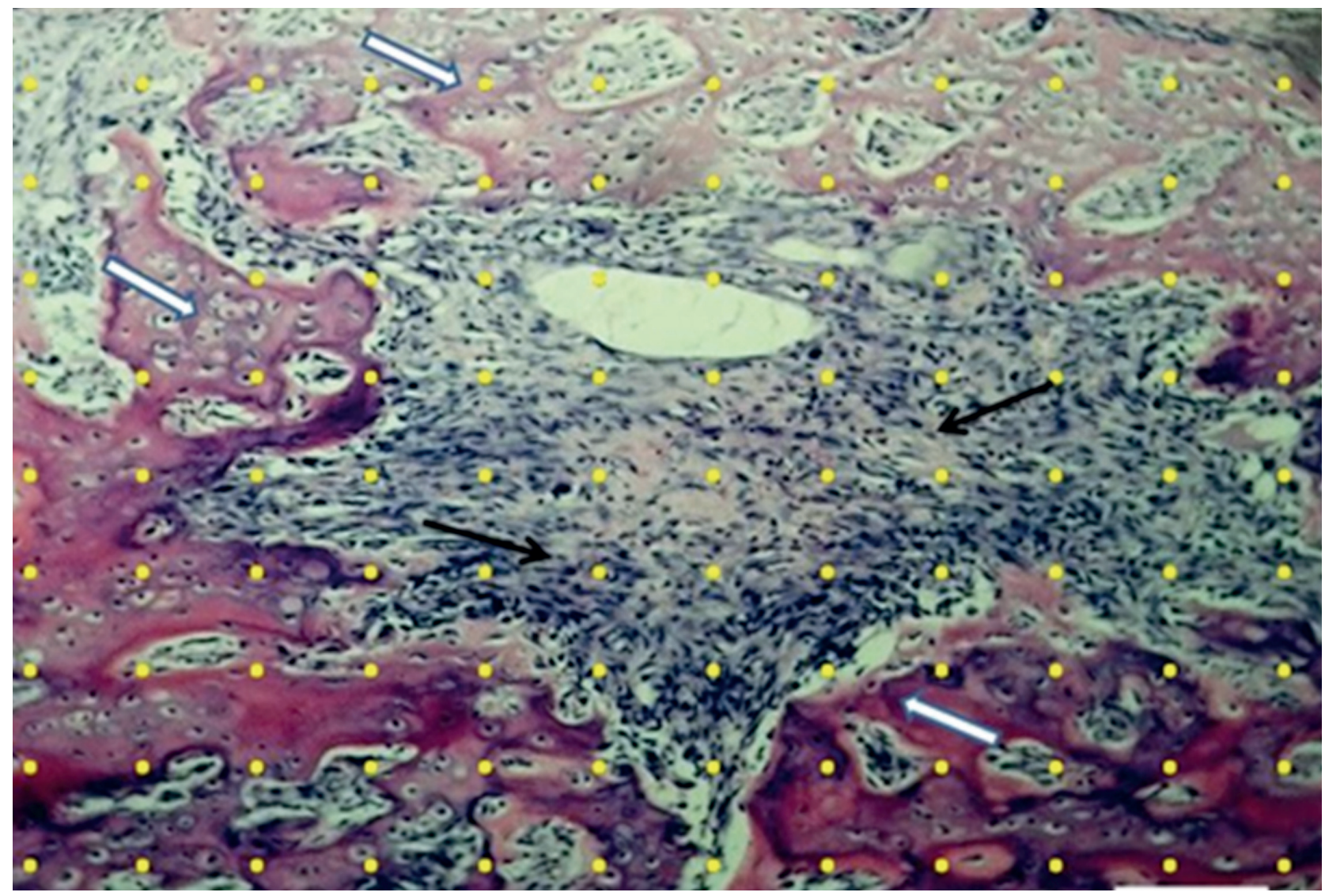

Figure 1 - Test-system with 132-points (yellow points) superimposed at a histological section from the fracture trace, used to quantify the newly formed bone (white arrows) in the four groups of rats

Note: Black arrows show nuclei of osteogenic cells. Bar: 100 micrometers $\mu \mathrm{m}$.

Source: Research data. 

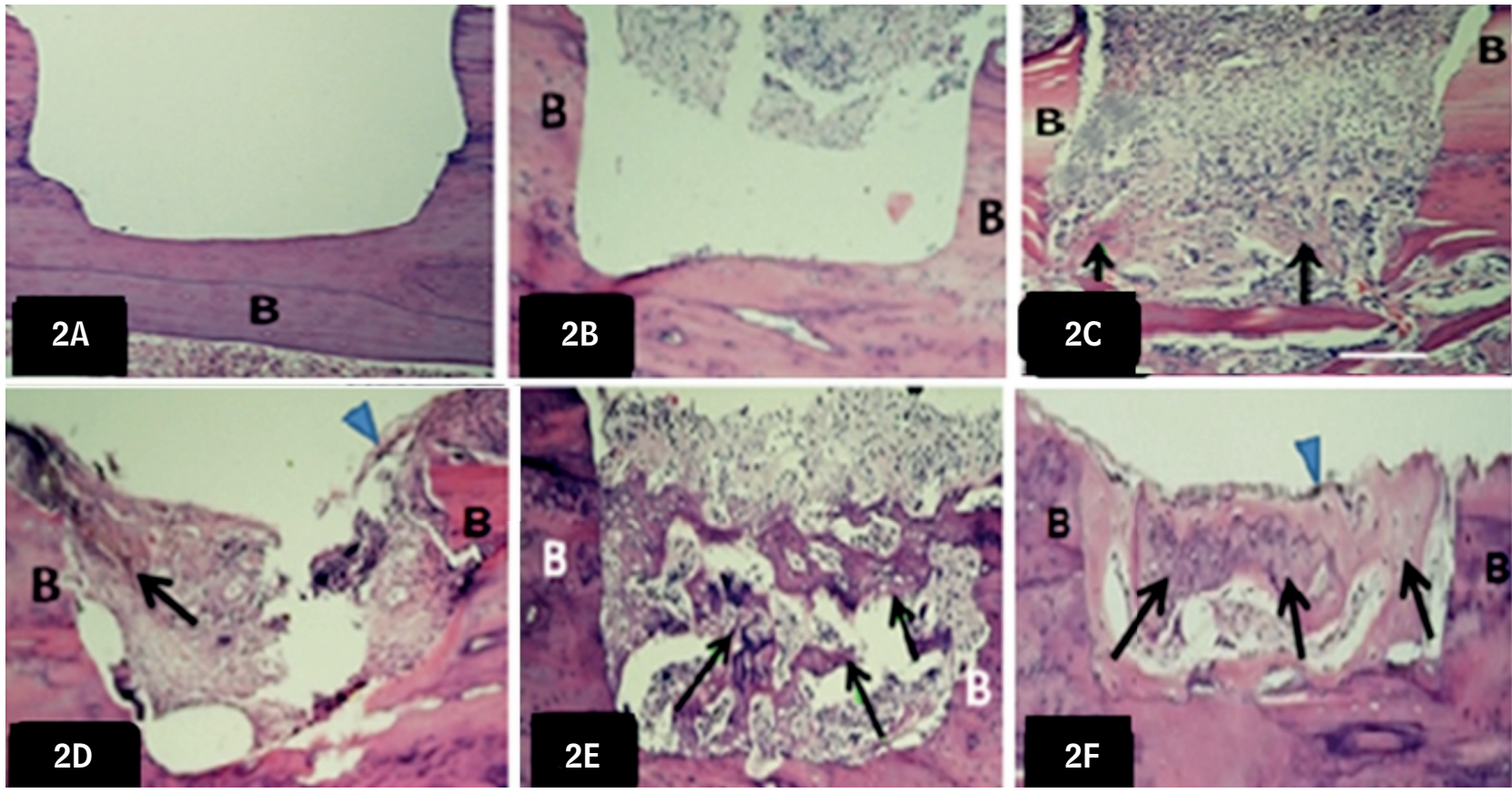

Figure 2 - Light micrographs of longitudinal sections of callus tissue stained with $\mathrm{HE}$

Note: A, D-C Group; B, E-L Group; C, F-I Group. 2 A, B, C - At the end of the first week; 2 D, E, F - At the end of the third week. New bone formation can be seen at the end of the first week ( $7^{\text {th }}$ day) in I group $(C)$ but not in the $C(A)$ or in $L$ Group (B). At the end of the twenty first week fractures treated with US of $1.0 \mathrm{~W} / \mathrm{cm}^{2}(\mathrm{~F})$ healed more rapidly than did that treated with US of $0.5 \mathrm{~W} / \mathrm{cm}^{2}(\mathrm{E})$ or the controls (D). Arrowheads - Periosteum. Arrows - Newly formed bone; B- Bone tissue. HE staining. Bar: 0.5mm.

Source: Research data.

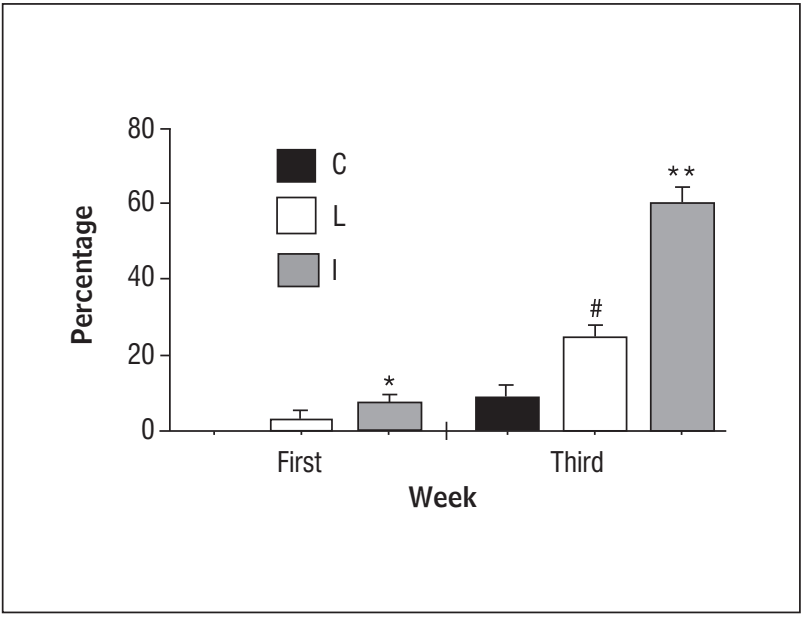

Figure 3 - Volume densities of newly formed bone in the callus tissue of $C, L$, and I groups of rats at the end of the $1^{\text {st }}$ and $3^{\text {rd }}$ week

Note: The use of ultrasound accelerated the consolidation process of the fracture, compared to the $\mathrm{C}$ group in both weeks. ${ }^{*}=$ Significant vs. $\mathrm{L}$ and $\mathrm{C}$ group at the first week; ${ }^{* *}=$ Significant vs. $\mathrm{L}$ and $\mathrm{C}$ group at the third week; ${ }^{*}=$ Significant vs. $\mathrm{C}$ group at the third week; $P<0.05$.

Source: Research data.
Assessment of the results of TUS application for the study of fracture healing with experimental animals has generally been done through X-ray or bone densitometry $(5,13,16,19,21,22)$. In the present work, results were obtained through histological and morphometric analysis of the fracture area. Only a few authors have used histological and quantitative methods for this purpose $(4,5,19)$ and none used histological methods associated with morphometric methods.

The pulsed TUS mode was used because it presents less thermal effect and because it has a proved action on the inflammatory reaction (23). However, some care must be taken when the TUS is used, as for example, to avoid direct contact of the head of the equipment with the surgical wound. In this study we used the application with the water balloon, because of the impossibility of immersion of the fractured area in the water, due to the limb immobilization through the plaster of Paris.

The exact mechanism of action of the ultrasound device is unknown. It has been theorized that the ultrasound pressure waves may mediate biologic 
activity directly by mechanical deformation of the cell membrane or the extracellular matrix or indirectly by an electrical effect caused by cell deformation (24, 25). Low intensity pulsed ultrasound in isolated cell systems produced significant multifunctional effects of direct relevance to bone formation and resorption such as increasing calcium uptake and modulating adenylate cyclase activity, transforming growth factor beta synthesis, bone morphogenic protein effects, and parathyroid hormone response $(11,26)$. Furthermore, ultrasound stimulation increases the mechanical properties of the healing fracture callus by stimulating earlier synthesis of extracellular matrix proteins in cartilage, possibly altering chondrocyte maturation and endochondral bone formation $(17,27)$. Others studies suggested that TUS acts on some cellular reactions involved in each phase of the healing process such as inflammatory reaction, angiogenesis, chondrogenesis, intramembranous ossification, endochondral ossification, and bone remodeling $(11,19)$. In summary, the application of ultrasonic waves of $1.0 \mathrm{~W} / \mathrm{cm}^{2}$ promoted a more rapid healing of experimental bone fractures than $0.5 \mathrm{~W} / \mathrm{cm}^{2}$ in Wistar rats.

\section{References}

1. Lirani APR, Larzaretti-Castro M. Evidências da ação de agentes físicos sobre o metabolismo do tecido ósseo e seus potenciais usos clínicos. Arq Bras Endocrinol Metab. 2005;49(6):891-96.

2. Alvarenga EC, Rodrigues R, Caricati-Neto A, Silva-Filho FC, Paredes-Gamero EJ, Ferreira AT. Low-intensity pulsed ultrasound-dependent osteoblast proliferation occurs by via activation of the P2Y receptor: role of the P2Y1 receptor. Bone. 2010;46(2):355-62.

3. Bazin S, Kitchen S. Eletroterapia de Clayton. São Paulo: Manole; 1998.

4. Takikawa S, Matsui N, Kokubu T, Tsunoda M, Fujioka H, Mizuno K, et al. Low-intensity pulsed ultrasound initiates bone healing in rat nonunion fracture model. J Ultrasound Med. 2001;20(3):197-205.

5. Zorlu U, Tercan M, Ozyazgan I, Taşkan I, Kardaş Y, Balkar F, et al. Comparative study of effect of ultrasound and electrostimulation on bone healing in rats. Am J Phys Med Rehabil. 1998;77 (5):427-32.
6. Matheus JP, Oliveira FB, Gomide LB, Milani JG, Volpon JB, Shimano AC. Effects of therapeutic ultrasound on the mechanical properties of skeletal muscles after contusion. Rev Bras Fisioter. 2008;12(3):241-7.

7. Chan CW, Qin L, Lee KM, Zhang M, Cheng JC, Leung KS. Low intensity pulsed ultrasound accelerated bone remodeling during consolidation stage of distraction osteogenesis. J Orthop Res. 2006;24(2):263-70.

8. Malizos KN, Papachristos AA, Protopappas VC, Fotiadis DI. Transosseous application of low-intensity ultrasound for the enhancement and monitoring of fracture healing process in a sheep osteotomy model. Bone. 2006;38(4):530-9.

9. Yang RS, Lin $\mathrm{WL}$, Chen $\mathrm{YZ}$, Tang $\mathrm{CH}$, Huang TH, Lu BY, et al. Regulation by ultrasound treatment on the integrin expression and differentiation of osteoblasts. Bone. 2005;36(2):276-83.

10. Hantes ME, Mavrodontidis AN, Zalavras CG, Karantanas AH, Karachalios T, Malizos KN. Low-intensity transosseous ultrasound accelerates osteotomy healing in a sheep fracture model. J Bone Joint Surg Am. 2004;86(10):2275-82.

11. Azuma Y, Ito M, Harada Y, Takagi H, Ohta T, Jingushi S. Low-intensity pulsed ultrasound accelerates rat femoral fracture healing by acting on the various cellular reactions in the fracture callus. Int J Bone Miner Res. 2001;16(4):671-80.

12. Tsai CL, Chang WH, Liu TK. Preliminary studies of duration and intensity of ultrasonic treatments on fracture repair. Chin J Physiol. 1992;35(1):21-6.

13. Fontes-Pereira AJ, Teixeira RC, Oliveira AJB, Pontes RWF; Barros RSM; Negrão JNC. The effect of low-intensity therapeutic ultrasound in induced fracture of rat tibiae. Acta ortop bras. 2013;21(1):18-22.

14. Gundersen HJ, Kroustrup JP, Vaeth M. Stereological analysis of three-dimensional structure organization of surfaces in multiphase specimens: statistical methods and model-inferences. J Microsc. 1988;149(Pt 2):135-52.

15. Englund U, Nordström P, Nilsson J, Bucht G, Björnstig U, Hallmans G, et al. Physical activity in middle-aged women and hip fracture risk: the UFO study. Osteoporos Int. 2011;22(2):499-505. 
16. Emami A, Petrén-Mallmin M, Larsson S. No effect of low-intensity ultrasound on healing time of intramedullary fixed tibial fractures. J Orthop Trauma. 1999;13(4):252-57.

17. Yang KH, Parvizi J, Wang SJ, Lewallen DG, Kinnick RR, Greenleaf JF, et al. Exposure to low intensity ultrasound increases aggrecan gene expression in a rat femur fracture model. J Orthop Res. 1996;14(5):802-9.

18. Rennó ACM, Faganello, FR, Navega MT, Carvalho DCL. The osteogenic effect of low intensity ultrasound. Fisioter Mov. 2001;14(2):52-7.

19. Kumagai K, Takeuchi R, Ishikawa H, Yamaguchi Y, Fujisawa T, Kuniya T, et al. Low-intensity pulsed ultrasound accelerates fracture healing by stimulation of recruitment of both local and circulating osteogenic progenitors. J Orthop Res. 2012;30(9):1516-21.

20. Hoppenfeld S, Vasantha L. Tratamento e reabilitação de fraturas. São Paulo: Manole; 2001.

21. Heybeli N, Yeşildag A, Oyar O, Gülsoy UK, Tekinsoy MA, Mumcu EF. Diagnostic ultrasound treatment increases the bone fracture-healing rate in an internally fixed rat femoral osteotomy model. Ultrasound Med. 2002;21(12):1357-63.

22. Sato W, Matsushita T, Nakamura K. Acceleration of increase in bone mineral content by low-intensity ultrasound energy in leg lengthening. J Ultrasound Med. 1999;18(10):699-702.

23. Khanna A, Nelmes RT, Gougoulias N, Maffulli N, Gray J. The effects of LIPUS on soft-tissue healing: a review of literature. Br Med Bull. 2009;89(1):169-82.
24. Sousa VL, Alvarenga J, Padilha Filho JG, Canola JC, Ferrigno CRA, Alves JM, et al. Ultra-som pulsado de baixa intensidade em fraturas diafisárias: aplicação clínica em cães. Ciênc Rural. 2008;38(4):1030-7.

25. Fréz AR, Ariza D, Ferreira JRL, Alves ÉPB, Breda GR, Centenaro LA, et al. Efeito do ultra-som terapêutico contínuo em placas epifisárias de coelhos. Rev Bras Med Esporte. 2006;12 (3):150-2.

26. Ryaby JT, Matthew J, Duarte-Alves P. Low intensity pulsed ultrasound affects adenylate cyclase activity and TGF- $\beta$ synthesis in osteoblastic cells. Trans Orthop Res Soc.1992;17:590.

27. Naito K, Watari T, Muta T, Furuhata A, Iwase H, Igarashi $\mathrm{M}$, et al. Low-intensity pulsed ultrasound (LIPUS) increases the articular cartilage type II collagen in a rat osteoarthritis model. J Orthop Res. 2010;28(3):361-9.

Received: 08/21/2013

Recebido: 21/08/2013

Approved: 01/19/2014

Aprovado: 19/01/2014 